InOedia $\quad \begin{aligned} & \text { InMedia } \\ & \text { The French Journal of Media Studies }\end{aligned}$

2| 2012

Performing/Representing Male Bonds

\title{
Contemporary Screen Narratives
}

17 May 2012, Department of Culture, Film and Media, University of Nottingham

Fabrice Lyczba

\section{OpenEdition}

12 Journals

Édition électronique

URL : http://journals.openedition.org/inmedia/482

DOI : 10.4000/inmedia.482

ISSN : 2259-4728

Éditeur

Center for Research on the English-Speaking World (CREW)

Référence électronique

Fabrice Lyczba, « Contemporary Screen Narratives », InMedia [En ligne], 2 | 2012, mis en ligne le 05 décembre 2012, consulté le 08 septembre 2020. URL : http://journals.openedition.org/inmedia/482 ; DOI : https://doi.org/10.4000/inmedia.482

Ce document a été généré automatiquement le 8 septembre 2020

(C) InMedia 


\section{Contemporary Screen Narratives}

17 May 2012, Department of Culture, Film and Media, University of Nottingham

Fabrice Lyczba

\section{NOTE DE L'ÉDITEUR}

Conference organized by Anthony Smith

1 The one-day conference entitled "Contemporary Screen Narratives", with its enticing plural, took place on May 17 at the Department of Culture, Film and Media at the University of Nottingham (UK) - a Department chaired by Professor Roberta Pearson. The conference, organized by Anthony Smith, featured an exciting mix of presentations from current $\mathrm{PhD}$ candidates, emerging scholars and well-established authorities, mostly from UK institutions - with the addition of representatives from Turkey, Spain, Italy and Ireland - and a no-less impressive display of presentation tools (for example Prezi, with its dynamic thought-mapping potential) and social media technologies, with scholars in the audience engaging in online debates during live presentations (a virtual conference, as it were, running in parallel to real-life discussions on Twitter and Facebook). As a side note, an intriguing article could, one imagines, be written on how the latest media tools are currently transforming the conference space and accelerating the spread of ideas, a particularly pregnant question at a conference aiming to understand the circulation of narrative content across cutting-edge media platforms.

2 Foregrounding present contemporary screen storytelling practices in all their production, distribution and consumption complexity, the day offered a unique opportunity to come to terms with the burgeoning field of transmedia studies, with case studies ranging geographically from US to Turkish media, but also diachronically from the most recent (2011) iterations of transmedia audience engagement through social web media tools to the interactions of fandom, comics and marketing in 1940s Classical Hollywood. A recent field of research in media studies launched by Henry 
Jenkins's widely influential Convergence Culture: Where Old and New Media Collide (2006), and inspired (at least initially) by the development of modern communication technologies and their use in film distribution and film reception (from webpages to social Internet tools, to comic books, video-games, and Alternate Reality Games), transmedia studies have since been raising central issues in film theory, revolving around questions of audience engagement through intertextuality, multimodality (how narratives adapt to different media) and additive comprehension (when transmediality participates in narrative world-building, as opposed to merely franchising). When do texts in fact circulate, and when is it simply branding? What is it that does circulate when a text changes media platform? What forms does audience engagement take, in transmedia distribution and reception? In the model of transmedia additive comprehension, how is narrative coherence maintained? This conference was to suggest several possible answers through precise case studies and expose the lines of debate in current research being carried out across Europe. Contemporary screen narratives, it suggested, are indeed plural in at least two ways: in the way transmedia distribution and reception opens up each screen narrative to multiple variations; and in the way this renewed focus on the plurality of texts, to paraphrase Barthes, opens up film history to a plurality of narratives, in line with the search for cinema's futures and pasts (cinema's alternative histories) that Thomas Elsaesser has proposed in the last ten years.

Organized in the traditional 'simultaneous panel' format allowing for an impressive thirty-eight papers in one day, the conference also featured two longer keynote presentations, one by American TV scholar Jason Mittell, the other - clearly the highlight of this stimulating day - by transmedia studies guru Henry Jenkins, appearing here in one of his many stops on his current European tour. One of the many possible subtitles to this conference could thus have been "Henry Jenkins meets Europe", as the focus of the day seemed to have been to showcase recent European work by a wide variety of international media scholars in the presence of the founder of transmedia studies, and allowing, as it were, for an up-to-date appreciation of the current situation of the field - and the pervasive influence that Professor Jenkins's insights on 'convergence culture' have had outside of the United States. Judging by the wealth of studies represented at this conference, transmedia studies are alive and well in the academic world, as convergence culture is happening around the globe in both industry and audience practices.

The first panel of the day looked at the question of 'interactivity' and raised the issue of whether audience engagement with film texts could be analyzed, beyond the familiar model of immersion, as a more active, but also more video-gaming, interactive relationship. Two examples in particular were presented. Dr Sarah Atkinson, of the University of Brighton, who has explored issues of contemporary media engagement both in her research and in her practical work (see her interactive cinema installation "Crossed Lines"), presented the transmedia experience built around the self-advertised "first ever social film", The Inside Experience (D.J. Curaso, 2011). A film, a video game, a puzzle, The Inside Experience also offered interactive role-playing possibilities to its fan community through the Facebook pages of its main characters, which allowed users/ viewers to comment on fictional character Christina Perasso's actions in the film and offer her guidance. In such transmedia experience, metalepsis (the crossing of narrative boundaries as expounded by Gérard Genette) is at the very heart of the film's reception, since the film text co-exists across several media platforms simultaneously and creates 
audience engagement on three levels: on a textual level (following plot), on a paratextuel level (with issues, among fans, of how their Facebook activity could help the film character or not: fans, in other words, establishing the rules of engagement with the fictive universe), and on a meta-textual level when the fictive experience seems to move beyond fiction to become, through the use of interactive social media and the increasing sophistication of young audiences' media literacy, 'real'. In their copresentation, Amy Chambers and Lyle Skains, of Bangor University, looked at another way of engaging audiences through what they termed "a multimodal text": the film Scott Pilgrim vs. The World (Edgar Wright, 2010). With its many references to Gen X video-game graphics, comics, and musical culture (the way the film, for instance, stages fight scenes as in Arcade-style video-games, or incorporates thought bubbles as in comic books), Scott Pilgrim, they argued, offers a case study of "tele-presence" ${ }^{1}$ for the fan, a model of virtual interaction with the film text - beyond the model of film-based passive viewing. Film narrative in this case becomes "participatory narrative" through an "aesthetics of artifice" that offers viewers the possibility of engagement with the film text by importing modes of engagement from his or her experience of other media (from watching someone else play a video-game to reading a comic book) - and where film narrative, in other words, becomes (at least potentially) hypertext. The theoretical framework is not new - as Umberto Eco suggested as early as the 1960s, mass media, by its multimodal, derivative nature, is inherently participatory in this sense - but one must admit that Scott Pilgrim offers a particularly clear example of a form of audience engagement through cinema's hypertextual referentiality - a modern example of the participatory nature of film reception that has been well explored for early, 1900-1910 cinema (Miriam Hansen), but under-researched for later periods of cinema history.

The two afternoon panels shifted the focus of the transmedia transformation away from audiences' activities and more to issues of content, questioning that grey zone where transmedia happens, with one foot in narrative content, and the other in marketing and promotion. The 'transmedia' panel was organized around presentations exploring the impact of transmedia marketing on narrative contents. Tom Phillips, of the University of East Anglia, concluded from his study of the transmedia distribution of TV series Psychoville (Reece Shearsmith and Steve Pemberton, 2009-2011, BBC2) that in transmedia marketing, content would seem to matter less than media: the Psychoville transmedia experience, expanding to web pages 'maintained' by fictive characters or to 'their' YouTube channel, is thus able to extend the horror/comedy tension inherent in the TV series to all parts of its universe by relying less on narrative consistency (narrative contents varying as they spread across platforms) and more on audiences' media literacy to maintain the film's tone of distancing irony. Tonguc Ibrahim Sezen (Istanbul University) presented a coauthored study of a particularly dynamic case of transmedia marketing in the distribution of Turkish TV series Valley of the Wolves / Kurtlar Vadisi (Serdar Akar, Mustafa Sevki Dogan, Osman Sinav, 2003-2005, Show TV). Not only is there an Alternate Reality Game available for Turkish fans of the series, integrating the fictional film universe with reality, but the reverse integration of reality within the fictional spy world is also made to appear seamless, with fictive characters discussing real-life news events a mere few days after the news has broken or offering in-show predictions about future real-life events. Such strategies, the authors propose, generate a "reverse Alternate Reality Game" where reality becomes part of the world being built by fiction, whether because, when real-life events conform to in-show forecasts, fans turn to conspiracy theories to describe the show creators as 
controlling real-life events, or whether fans take inspiration from the show to engage in community-based action in the real world (such as community engagement against Big Oil). Matthew Freeman (University of Nottingham) proposed, from the study of the transmedia universe of the Superman comics and cartoons in the late 1930s, that transmedia be seen less as a product of convergence and more as a process - a process, importantly, that did not wait for new contemporary media to develop but has existed in Hollywood for a long time. His research shows how this process may come to crossinfluence content across the several platforms where it is explored: Superman, after all, only learnt to fly in the D.C. comics after the change was introduced in the film cartoon series. In those three case studies, thus, the 'bleeding over' of content across media is situated differently: in Psychoville's multimodality, in aggressive metalepsis through active referencing of reality for Valley of the Wolves, or in a creative process that did not wait for media convergence to exist in cinema for the Superman cartoons.

Veering more resolutely to questions of the impact of transmedia marketing on production, the "industry/production" panel consisted of several recent case studies of how media producers are integrating audience engagement within their product(ion)s. Sophie Halliday (University of East Anglia) looked at the impact of fan communities on the development (and sheer survival) of US series Fringe (J.J. Abrams, Alex Kurtzman, Roberto Orci, 2008-2012, Fox Network), "probably the first ever series to be saved by a hashtag." Gloria Dagnino (University of Italian Switzerland) presented findings from her on-going $\mathrm{PhD}$ research about changing tax rules in Italian law that make it financially more interesting for companies to fund filmmakers in exchange for product placement - a practice that is starting to have an impact even on Italian 'auteur' cinema as it forces filmmakers to adapt diegetic worlds to financing pressures. By looking at commercial modes of engagement of films, the panel suggested that film texts do not, in fact, exist in splendid isolation and that the profit incentive, in itself, is already fertile ground for content cross-proliferation.

7 The day's panels, thus, established as a key focus of the symposium the question of the nature of transmedia: should it be theorized as mostly promotion (as in the linkage between film fictions and commercial products advertised through the film), or, more intriguingly, as mostly content - that is, storytelling through other means? Following Henry Jenkins's oft-quoted definition of transmedia narrative as "unified and coordinated" across media platforms, ${ }^{2}$ should transmedia narrative practices be restricted to cases of narrative expansion, or could it come to include cases of narrative reduction, as media scholar Carlos Scolari (Universitat Pompeu Fabra, Barcelona) proposed with his analysis of Spanish TV series The Triplets / Les Tres Bessones (Robert Balser, Baltasar Pedrosa, 1995-2003, Televisió de Catalunya TV3) as a case study of what he proposes to call "the narrative accordion"? The two keynotes, in different ways, returned to these issues of defining transmedia and its reach - content vs promotion, expansion vs reduction - and offered contrasting answers. Jason Mittell's presentation on TV series' 'infamous' heroes (the antiheroes of Breaking Bad, Dexter, The Sopranos or Mad Men), while not directly concerned with transmedia storytelling, was nonetheless an offshoot from his soon-to-be-published book on ComplexTV: The Poetics of Contemporary Television Storytelling, where such issues are explored as part of new narrative complexities he has identified in contemporary American TV series. ${ }^{3}$ For Mittell, transmedia must be distinguished from more general paratexts of media production - commercial clutter that does not offer narrative expansion but serves merely as an introduction to the film or TV text. In the concluding lecture of the day, 
Henry Jenkins on the other hand aimed to move beyond such dichotomy by including paratexts (such as bench advertising in the streets of Los Angeles for the release of District 9) as part of the immersive experience that transmedia, whether as promotion or content, proposes audiences. Reworking some of the issues broached in the different panels of the day, but with the goal of offering an expanded theoretical framework, Jenkins's lecture reframed transmedia studies within the larger scope of "participatory culture", and suggested the development of a "media archaeology" perspective in transmedia studies. Starting with examples of how contemporary communication technologies have helped today's fans to become active participants and transmedia creators of screen narratives, Jenkins then invited scholars to look beyond contemporary technologies to the larger history of "the 200 years of grass-root movements trying to gain access to the tools of cultural production." Beyond web 2.0 social media tools, a whole new field, Jenkins suggested, awaits scholars wishing to look at technologies that have allowed media contents to circulate throughout history by offering "systems of spreadability." In this framework of a history of technologies that have allowed texts and contents to spread, under the control or not of production authorities, Gutenberg's printing press, Jenkins suggested, would thus become "web minus 10.0".

Thus transmedia, in situating film narratives within a larger technological history of media, could rejoin not just fan studies but also, more generally, other fields of media studies currently undergoing exciting development, from game studies (A. Blanchet) to software studies (L. Manovich) and media archaeology (E. Huhtamo). Importantly, media (including film) is here proposed as inherently participatory - as fiction universes to be played with, re-organized, expanded, reduced, transformed by audiences throughout the technological history of images and screens. This, to me, represents a salutary and generous call on Professor Jenkins's part to consider media fictions in all their circulation - a call which opens up intriguing possibilities to study all media texts, contemporary and past, New Hollywood or Classical, once more in their reception dynamic.

\section{NOTES}

1. Matthew Lombard and Theresa Ditton, "At the Heart of It All: The Concept of Presence," Journal of Computer-Mediated Communication vol. 3 no. 2 (1997).

2. Henry Jenkins, "Transmedia 202: Further Reflections," August 1, 2011, Confessions of an Aca/Fan, accessed June 27, 2012, http://henryjenkins.org/2011/08/defining_transmedia_further_re.html.

3. The book is offered as open source in pre-publication mode through the CommonsMedia website

(http://tinyurl.com/complextv) - which is another sign of the conference organizers' and panelists' unequivocal embrace of new technologies as enhancers of scholarly interaction. 
AUTEUR

FABRICE LYCZBA

Université Paris Est Créteil 